\title{
Antimicrobial Activity of Chemically and Biologically Treated Chitosan Prepared from Black Soldier Fly (Hermetia illucens) Pupal Shell Waste
}

\author{
Mevin Kiprotich Lagat ${ }^{1}$, Samuel Were ${ }^{1}$, Francis Ndwigah ${ }^{1}$, Violah Jepkogei Kemboi ${ }^{1}$, Carolyne Kipkoech ${ }^{2, *}$ \\ and Chrysantus Mbi Tanga ${ }^{3}$ (D) \\ 1 Department of Botany, Jomo Kenyatta University of Agriculture and Technology, \\ Nairobi P.O. Box 62000-02000, Kenya; mlagat237@gmail.com (M.K.L.); samaringo@gmail.com (S.W.); \\ irerifin@gmail.com (F.N.); violahkemboi42@gmail.com (V.J.K.) \\ 2 Department of Food and Nutritional Sciences, Jomo Kenyatta University of Agriculture and Technology, \\ Nairobi P.O. Box 62000-02000, Kenya \\ 3 International Centre of Insect Physiology and Ecology (icipe), Nairobi P.O. Box 30772-00100, Kenya; \\ ctanga@icipe.org \\ * Correspondence: kipkoechcarolyne@gmail.com
}

\section{check for}

updates

Citation: Lagat, M.K.; Were, S.; Ndwigah, F.; Kemboi, V.J.; Kipkoech, C.; Tanga, C.M. Antimicrobial Activity of Chemically and Biologically Treated Chitosan Prepared from Black Soldier Fly (Hermetia illucens) Pupal Shell Waste. Microorganisms 2021, 9, 2417. https://doi.org/10.3390/ microorganisms 9122417

Academic Editor: Maurizio Cian

Received: 28 October 2021

Accepted: 17 November 2021

Published: 23 November 2021

Publisher's Note: MDPI stays neutral with regard to jurisdictional claims in published maps and institutional affiliations.

Copyright: (c) 2021 by the authors. Licensee MDPI, Basel, Switzerland. This article is an open access article distributed under the terms and conditions of the Creative Commons Attribution (CC BY) license (https:// creativecommons.org/licenses/by/ $4.0 /)$.

\begin{abstract}
Globally, the broad-spectrum antimicrobial activity of chitin and chitosan has been widely documented. However, very little research attention has focused on chitin and chitosan extracted from black soldier fly pupal exuviae, which are abundantly present as byproducts from insectfarming enterprises. This study presents the first comparative analysis of chemical and biological extraction of chitin and chitosan from BSF pupal exuviae. The antibacterial activity of chitosan was also evaluated. For chemical extraction, demineralization and deproteinization were carried out using $1 \mathrm{M}$ hydrochloric acid at $100{ }^{\circ} \mathrm{C}$ for $2 \mathrm{~h}$ and $1 \mathrm{M} \mathrm{NaOH}$ for $4 \mathrm{~h}$ at $100{ }^{\circ} \mathrm{C}$, respectively. Biological chitin extraction was carried out by protease-producing bacteria and lactic-acid-producing bacteria for protein and mineral removal, respectively. The extracted chitin was converted to chitosan via deacetylation using $40 \% \mathrm{NaOH}$ for $8 \mathrm{~h}$ at $100{ }^{\circ} \mathrm{C}$. Chitin characterization was done using FTIR spectroscopy, while the antimicrobial properties were determined using the disc diffusion method. Chemical and biological extraction gave a chitin yield of $10.18 \%$ and $11.85 \%$, respectively. A maximum chitosan yield of $6.58 \%$ was achieved via chemical treatment. From the FTIR results, biological and chemical chitin showed characteristic chitin peaks at 1650 and $1550 \mathrm{~cm}^{-1}$-wavenumbers corresponding to amide I stretching and amide II bending, respectively. There was significant growth inhibition for Escherichia coli, Bacillus subtilis, Pseudomonas aeruginosa, Staphylococcus aureus, and Candida albicans when subjected to 2.5 and $5 \%$ concentrations of chitosan. Our findings demonstrate that chitosan from BSF pupal exuviae could be a promising and novel therapeutic agent for drug development against resistant strains of bacteria.
\end{abstract}

Keywords: insects; Hermetia illucens; pupal exuviae; chitin; chitosan; antimicrobial activity keyword

\section{Introduction}

Chitin is a natural polysaccharide that exists as the second most common polymer after cellulose [1]. It occurs as a structural component in most crustacean shells, the pupal exuviae of some insects, and in the cell membranes of fungi [2]. Currently, chitin and chitosan have garnered attention for extensive applications in wastewater treatment, the pharmaceutical industry, food manufacturing, and agriculture [3-6]. This is because they possess various unique properties, including biocompatibility, biodegradability, nontoxicity, and antimicrobial activities [7].

Extraction of chitin and chitosan can be performed using chemical and biological methods [8]. The process involves three steps: deproteinization, demineralization, and deacetylation for the conversion of chitin to chitosan. The chemical method uses acids 
and bases such as hydrochloric acid and sodium hydroxide for the removal of minerals and proteins, respectively [9]. High concentrations of these chemicals severely pollute the environment, affect the physicochemical properties of chitin and chitosan, and are also expensive [10]. To overcome these challenges, there is an alternative to using biological chitin extraction methods, involving the utilization of microorganisms such as lactic-acidproducing bacteria for demineralization and proteolytic bacteria for deproteinization. The deacetylase enzyme is then used for the biological conversion of chitin to chitosan [11]. Biological extraction of chitin offers high reproducibility, is simpler to manipulate, requires a small number of solvents-making it cheaper-and is eco-friendly, with a lower energy input.

Several studies have focused on chitin extracted from arthropods such as millipedes, beetles, and grasshoppers [12-14], as well as from mushroom species such as Pleurotus ostreatus, Ganoderma lucidum, and Agaricus bisporus [15-17]. However, not much work has been done on the black soldier fly, Hermetia illucens L. To the best of our knowledge, this is the first report on the biological extraction of chitin from BSF pupal exuviae (i.e., a byproduct abundantly available and highly accessible year-round in commercial production facilities worldwide) using bacteria. Herein, the percentage yield of chitin and chitosan was determined before characterization using Fourier-transform infrared spectra and scanning electron microscopy. The efficiency of biological and chemical extraction methods was established to understand the economic viability of both methods. Finally, the antimicrobial activities of chitosan against selected clinical pathogenic bacteria were tested.

\section{Materials and Methods}

\subsection{Study Site}

This research was conducted at the Jomo Kenyatta University of Agriculture and Technology (JKUAT), $30 \mathrm{~km}$ northeast of Nairobi metropolis, at the Government of Kenya (GoK) Botany Laboratory (10180S,370E). The pupal exuviae from which both chitin and chitosan were extracted was obtained from the BSF mass production facility at the Animal Rearing and Containment Unit (ARCU) at the International Centre of Insect Physiology and Ecology (icipe), Nairobi, Kenya.

\subsection{Chemical Extraction of Chitin from Hermetia illucens Pupal Exuviae}

The BSFs were reared following the standard operating procedures at icipe [18]. The samples were collected after three independent rearing periods in April, July, and September 2020. The pupal exuviae were sorted, washed in water, and blended into a fine powder using a commercial laboratory blender (Sanyo SM-1250 GC, Zhongshan, China). One hundred grams of the resultant powder was weighed using an analytical balance (RADWAG, model WTB 2000, Radom, Poland), and treated with $1000 \mathrm{~mL}$ of $1 \mathrm{M}$ sodium hydroxide (Sigma-Aldrich, St. Louis, MI, USA) and allowed to boil for $4 \mathrm{~h}$, with continuous stirring to remove proteins. The product was thoroughly washed with distilled water until reaching a neutral $\mathrm{pH}$. The $\mathrm{pH}$ was measured using the HANNA HI $2211 \mathrm{pH} / \mathrm{ORP}$ Meter (Helsinki, Finland). The product was then dried at a temperature of $60^{\circ} \mathrm{C}$ for $24 \mathrm{~h}$ using a hot-air oven (GRANDE GMH-225, Dongguan, China). Calcium carbonate was removed from the dried sample by treating it with $1000 \mathrm{~mL}$ of $1 \mathrm{M}$ hydrochloric acid (Sigma-Aldrich, MI, USA) and allowing it to boil for $2 \mathrm{~h}$. The final product was rinsed in distilled water until a neutral $\mathrm{pH}$ was achieved; it was then dried in a hot-air oven at a temperature of $60{ }^{\circ} \mathrm{C}$ for $24 \mathrm{~h}$. The final dried product was weighed, and the percentage yield of chitin was calculated from the initial pupal exuviae used, following the method used in [19]. All procedures were carried out in triplicate.

\subsection{Biological Extraction of Chitin from Hermetia illucens Pupal Exuviae}

\subsubsection{Bacteria Isolates}

Biological extraction of chitin was carried out using protease-producing bacteria (Bacillus subtilis and Pseudomonas aeruginosa) and lactic-acid-producing bacteria (Lactobacil- 
lus plantarum) following the method described in [20], with slight modifications. The isolates used were obtained from the JKUAT food microbiology and botany laboratories. These isolates were used because they have been reported to give high yields in chitin extraction [8].

\subsubsection{Biological Extraction}

There were two sets of experiments: In the first setup, deproteinization was performed using proteolytic bacteria-namely, Bacillus subtilis and Pseudomonas aeruginosa-followed by demineralization using Lactobacillus plantarum. In the second series of experiments, demineralization was performed followed by deproteinization. Each of the sets of experiments was replicated three times to increase the reliability and accuracy of the results obtained, and repeated for the three different independent samples.

\subsubsection{Deproteinization and Demineralization}

During the deproteinization process, $100 \mathrm{~g}$ of the pupal exuviae flour was soaked in $2 \mathrm{~L}$ of distilled water. To this mix, $55 \mathrm{~g}$ of sucrose (Sigma-Aldrich, St. Louis, MI, USA) was added, and the mixture was then inoculated with $10 \mathrm{~mL}$ of Bacillus subtilis and Pseudomonas aeruginosa and incubated at $37^{\circ} \mathrm{C}$ for 5 days. After 5 days, the deproteinized material was sterilized by autoclaving for $15 \mathrm{~min}$ at $121^{\circ} \mathrm{C}$ using an IKENOHATA AL-300 autoclave (Sibata Scientific Technology Ltd., Tokyo, Japan), and then demineralized by inoculating it with $10 \mathrm{~mL}$ of Lactobacillus plantarum and incubating it at $37^{\circ} \mathrm{C}$ in anaerobic conditions for another 5 days [21].

For co-cultivation of B. subtilis and P. aeruginosa in chitin extraction, $100 \mathrm{~g}$ of the pupal exuviae powder was soaked in $2 \mathrm{~L}$ of distilled water. To this mix, $55 \mathrm{~g}$ of sucrose (Sigma-Aldrich, MI, USA) was added, and the mixture was then inoculated with $10 \mathrm{~mL}$ of B. subtilis and P. aeruginosa, and incubated at $37^{\circ} \mathrm{C}$ for 5 days using a JSI 102 incubator Patna, India). After 5 days, the deproteinized material was sterilized and then demineralized by inoculating it with $10 \mathrm{~mL}$ of L. plantarum, and incubated at $37^{\circ} \mathrm{C}$ in anaerobic conditions for another 5 days.

\subsection{Deacetylation of Chitin to Chitosan}

The extracted chitin from $H$. illucens pupal exuviae was then converted into chitosan by refluxing $200 \mathrm{~g}$ in $1000 \mathrm{~mL}$ of $40 \% \mathrm{NaOH}$ (Sigma-Aldrich, St. Louis, MI, USA) solution and boiling for $8 \mathrm{~h}$. The deacetylated chitosan was then cleaned with sterile water to neutral $\mathrm{pH}$ and dried in a hot-air oven at $60{ }^{\circ} \mathrm{C}$. The dried samples were then stored at $4{ }^{\circ} \mathrm{C}$ in airtight plastic containers until use.

\subsection{Determination of Percentage Yield of Chitin and Chitosan}

The chitin yield was calculated based on the dry weight using gravimetric measurements between the raw pupal shell waste and the chitin that was obtained after the extraction process. This was done after drying the pupal exuviae, chitin, and chitosan to a constant weight to ensure that the difference in weight was not attributed to the moisture content. Furthermore, the chitosan yield was calculated based on the dry weight from the weight difference between the chitin that was obtained and the chitosan that was obtained after the chitosan production process, using the following equations:

$$
\text { Chitin yield }(\%)=\frac{\mathbf{a}}{\mathbf{b}} \times 100
$$

where $\mathbf{a}$ is the obtained chitin weight $(\mathrm{g})$ and $\mathbf{b}$ is the pupal shell waste weight $(\mathrm{g})$.

$$
\text { Chitosan yield }(\%)=\frac{\mathbf{c}}{\mathbf{d}} \times 100
$$

where $\mathbf{c}$ is the weight $(\mathrm{g})$ of chitosan that was obtained, while $\mathbf{d}$ is the weight $(\mathrm{g})$ of chitin that was prepared. 


\subsection{Characterization of Chitin and Chitosan by Fourier-Transform Infrared (FTIR) Spectroscopy}

The FTIR measurements were done following the method described in [22], using FTIR with a scanning range of 4000 to $400 \mathrm{~cm}^{-1}$ (BRUCKER, model ALPHA, Berlin, Germany).

\subsection{Characterisation of Chitin and Chitosan by Scanning Electron Microscopy (SEM)}

The surface morphologies of chitosan and chitin samples were determined using a JCM-7000 NeoScope Benchtop scanning electron microscope (JEOL Ltd., Tokyo, Japan). The samples were coated with carbon film and examined using the secondary electron mode with an accelerating voltage of $15 \mathrm{Kv}$ to show microstructures at different magnifications.

\subsection{Antimicrobial Activities}

\subsubsection{Test Organisms for Antimicrobial Assay}

The antimicrobial activities of chitosan were tested against two Gram-negative bacteriaEscherichia coli ATCC $^{\circledR} 25922$ (E. coli) and Pseudomonas aeruginosa ATCC $^{\circledR} 27853$ (P. aeruginosa) - two Gram-positive bacteria-Staphylococcus aureus ATCC ${ }^{\circledR} 25923$ (S. aureus) and Bacillus subtilis ATCC ${ }^{\circledR} 11778$ (B. subtilis)—and the yeast Candida albicans ATCC $^{\circledR} 10231$ (C. albicans). The test microbes were obtained from medical microbiology and Government of Kenya (GoK) laboratories at JKUAT.

\subsubsection{Inoculum and Sample Preparation}

Each bacterial strain was sub-cultured overnight at $37^{\circ} \mathrm{C}$ in nutrient broth (SigmaAldrich, St. Louis, MI, USA), while C. albicans was sub-cultured overnight at $37^{\circ} \mathrm{C}$ in Sabouraud dextrose broth (Sigma-Aldrich, MI, USA), and then on agar plates. Bacterial colonies were thereafter suspended in $9 \mathrm{~mL}$ of sterile saline solution, and the suspension was adjusted to achieve turbidity equivalent to the $0.5 \mathrm{McF}$ arland standard, which is equivalent to $1 \times 10^{8}$ colony-forming units $(\mathrm{CFUs}) / \mathrm{mL}$. Mueller-Hinton agar (SigmaAldrich, St. Louis, MI, USA) was then prepared, and $12 \mathrm{ml}$ of the medium was dispensed to the Petri dishes and allowed to solidify.

\subsubsection{Antimicrobial Susceptibility Assay}

The Kirby-Bauer disc diffusion method was employed in this study for antimicrobial assay [23]. Typically, $20 \mu \mathrm{L}$ of freshly prepared McFarland bacterial cultures of E. coli, S. aureus, P. aeruginosa, and $B$ subtilis, as well as a fungal culture of $C$. albicans, were then inoculated and spread uniformly onto Mueller-Hinton agar plates. Chitosan sample discsprepared by impregnating $50 \mu \mathrm{L}(250 \mu \mathrm{g} /$ disc $)$ of chitosan solution on sterile filter paper discs $(6 \mathrm{~mm})$, followed by air-drying - were placed on the top of the agar plates. The plates were then incubated at $37^{\circ} \mathrm{C}$ for $24 \mathrm{~h}$ using an IS62 incubator (Genlab, Tokyo, Japan). The presence of inhibition zones was measured around each disc in millimeters $(\mathrm{mm})$ and was considered as evidence of antimicrobial activity. The experiments for each test organism were carried out in triplicate. Filter-paper discs soaked in $2 \mathrm{~mL}$ of $1 \%$ acetic acid (SigmaAldrich, MI, USA) without chitosan were used as a positive control, while sterile distilled water was used as a negative control. The effects of BSF chitosan were also compared to a group of standard reference antibiotics (Alpha Medical Manufacturers, Nairobi, Kenya) including ampicillin $(25 \mathrm{mcg})$, streptomycin $(25 \mathrm{mcg})$, tetracycline $(100 \mathrm{mcg})$, nalidixic acid (30 mcg), chloramphenicol (25 mcg), clotrimazole ( $25 \mathrm{mcg})$, and nitrofurantoin (200 mcg) to ascertain whether chitosan can be used as an antibiotic compound.

\subsection{Data Collection and Analysis}

Data on chitin yield were collected based on the dry weight using gravimetric measurements between the raw pupal shell waste and the chitin that was obtained after the extraction process. Data on the chitosan yield were collected based on the dry weight from the weight difference between the chitin that was obtained and the chitosan that was obtained after the chitosan production process. The data on antimicrobial activity were collected by measuring clear zones of inhibition around each disc on each plate of each test 
organism. Data analysis was done using Stata SE-64 2011 statistics software, and means were separated using the Bonferroni range test. Data on the chitin and chitosan yields were expressed as mean \pm standard deviation, and comparisons of mean yield between groups were performed by one-way analysis of variance. Similarly, the difference in the mean inhibition zone was measured using a one-way analysis of variance, and the difference was considered significant at $p \leq 0.05$.

\section{Results and Discussions}

\subsection{Chitin Yield from the Pupal Exuviae of the Black Soldier Fly}

The chitin yield obtained from co-cultivation of bacteria was significantly $(p>0.05)$ higher compared to each of the individual cultivated bacteria (Table 1). There was, however, a significant difference in the yields obtained from chemical and biological extraction methods with individual fermentation. Co-cultivation of bacteria gave the highest yieldalmost equal to the chemical extraction. In individual fermentation, P. aeruginosa gave the highest yield, while the lowest yield was obtained by B. subtilis. When the reverse order of extraction was employed (demineralization then deproteinization), there was an increase in the yield of chitin, with B. subtilis giving a higher yield than P. aeruginosa.

Table 1. Mean chitin yield (g) from biological and chemical extraction from the black soldier fly pupal exuviae.

\begin{tabular}{cc}
\hline Chitin Extraction Treatments & Chitin Yield(g) (Mean \pm S.D) \\
\hline B. subtilis + L. plantarum & $7.78 \pm 0.68^{\mathrm{a}}$ \\
P. aeruginosa + L. plantarum & $9.47 \pm 0.52^{\mathrm{b}}$ \\
L.plantarum + B. subtilis & $8.76 \pm 0.88^{\mathrm{b}}$ \\
L.plantarum +P.aeruginosa & $7.99 \pm 1.16^{\mathrm{a}}$ \\
Chemical extraction. & $11.85 \pm 1.16^{\mathrm{c}}$ \\
\hline - aeruginosa + B. subtilis + L. plantarum. & $10.18 \pm 0.42^{\mathrm{c}}$ \\
\hline Different letters in the same column indicate significant differences $(p<0.05)$. & $<0.001$ \\
mean \pm standard deviation. &
\end{tabular}

The chitin yield obtained from co-cultivation of bacteria was significantly $(p>0.05)$ higher compared to each of the individual cultivated bacteria (Table 1). There was, however, a significant difference in the yields obtained from chemical and biological extraction methods with individual fermentation. Co-cultivation of bacteria gave the highest yieldalmost equal to the chemical extraction. In individual fermentation, $P$. aeruginosa gave the highest yield, while the lowest yield was obtained by B. subtilis. When the reverse order of extraction was employed (demineralization then deproteinization), there was an increase in the yield of chitin, with B. subtilis giving a higher yield than P. aeruginosa.

The present findings on the yield obtained from both biological and chemical extraction differ from the findings reported by the authors of [24-26], who obtained slightly lower yields. This difference could be due to the use of pupal exuviae in the present study, while the previous studies used dead flies [27]. Our findings are consistent with those reported by the author of [19], who demonstrated that the sequence of extraction, deproteinization (DP), and demineralization (DM) can lead to a decrease in chitin yield. This is because DP before DM erodes the protein layer that covers the chitin matrix, exposing it to acidic treatment and causing significant removal of inorganic material. Significant hydrolysis and loss of chitin fraction resulted in a low yield of chitin [19]. The chitin yield obtained in this study via biological means differed from the results documented in [28], where the authors found a higher chitin yield from crabs [28]. This variation was due to different sources, such as marine organisms, fungi, and insects [29]. The results obtained from this study can be compared with the yield obtained from other insects-for example, grasshoppers, beetles, and Daphnia sp. [30-32]. In this study, the chitosan yield obtained from the BSF pupal exuviae $(6.58 \%)$ via chemical means was lower when compared to that reported 
in [19]. According to the findings of [19], the variation in chitosan yield may have been due to excessive depolymerization of the chitosan polymer, and loss of the sample due to excessive removal of acetyl groups during deacetylation. The chitosan yield obtained was also comparable to other sources, such as cockroaches, shrimp, Musca domestica, and krill [33-35].

\subsection{Analysis of Functional Groups in Chitin Extracted from the Black Soldier Fly}

There were similarities observed in the structure of chitin extracted through biological and chemical methods (Figure 1). Biologically extracted chitin exhibited vibration peaks at $3440,2355,1650$, and $1550 \mathrm{~cm}^{-1}$, while chemically extracted chitin showed vibration peaks at $3440,2355,1651$, and $1552 \mathrm{~cm}^{-1}$.

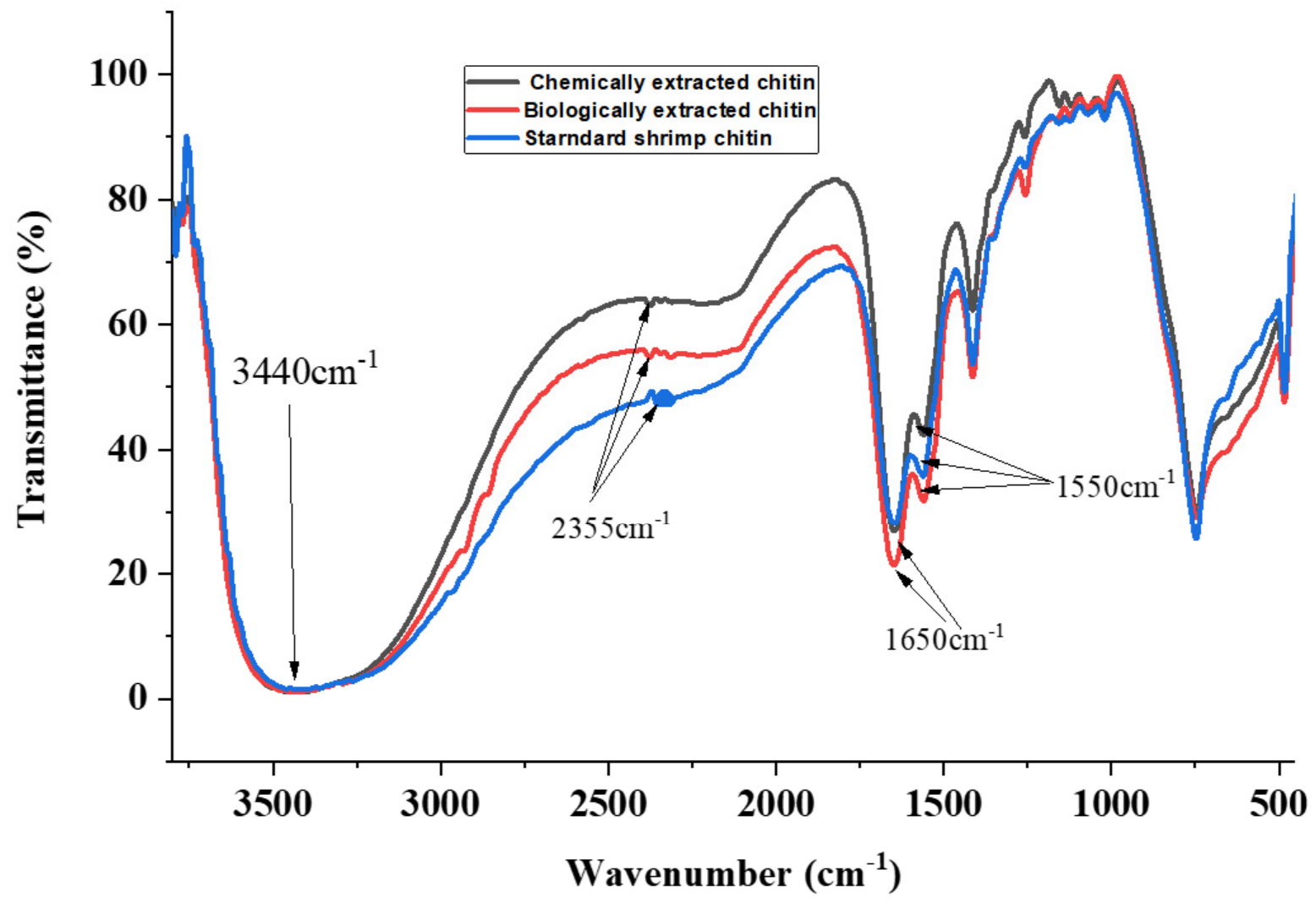

Figure 1. FTIR spectra of chitin extracted from BSF pupae shells via biological and chemical means, compared to commercial standard shrimp chitin (Sigma Aldrich, St. Louis, MI, USA).

Commercial shrimp chitin had peaks at 3440, 2355, 1652, and $1552 \mathrm{~cm}^{-1}$. The band at $3440 \mathrm{~cm}^{-1}$ was broad and was due to the presence of hydroxyl groups in the chitin. The band at $2355 \mathrm{~cm}^{-1}$ was attributed to the presence of $\mathrm{C}-\mathrm{H}$ stretching vibrations, which were indicative of the presence of methyl groups. Additionally, the band at $1650 \mathrm{~cm}^{-1}$ was attributed to $\mathrm{C}=\mathrm{O}$ secondary amide I stretching vibrations, while the band at $1550 \mathrm{~cm}^{-1}$ was attributed to amide II, which was indicative of N-H bending.

These findings were similar to those in [19], where the author used chitin from BSF larvae and adult flies, and obtained the same characteristic peaks. These results are also consistent with the findings of [30], where the authors used chitin from grasshoppers, and obtained the same characteristic bands $[19,36]$. This study revealed that the chitin extracted from the BSF pupal exuviae via biological and chemical means is of $\alpha$-form, and is very similar to that of commercial shrimp chitin. In the literature, it is reported that alpha ( $\alpha$ )-chitin has characteristic chitin peaks recorded at 1650,1620, and $1550 \mathrm{~cm}^{-1}$ [30].

In addition, [37] found that the presence of the glycosidic bond at $896 \mathrm{~cm}^{-1}$ is a characteristic band for alpha-chitin, which was detected in all chitin samples (Figure 1). It 
was found that there was no difference between the structures of biological, chemical, and shrimp chitin. In all of the chitin samples, there were no peaks at $1540 \mathrm{~cm}^{-1}$. The absence of bands at $1540 \mathrm{~cm}^{-1}$ could be attributed to the absence of protein contaminants showing sufficient deproteinization $[17,37]$.

Other major bands detected were $1413 \mathrm{~cm}^{-1}\left(\mathrm{CH}_{2}\right.$ ending and $\mathrm{CH}_{3}$ deformation), $1256 \mathrm{~cm}^{-1}$ (C-H bending and $\mathrm{CH}_{3}$ symmetrical deformation), $1069 \mathrm{~cm}^{-1}$ (asymmetric in-phase ring-stretching mode), $1023 \mathrm{~cm}^{-1}$ (C-O-C asymmetric in-phase ring-stretching), $1159 \mathrm{~cm}^{-1}\left(\mathrm{CH}_{2}\right.$ wagging), $1114 \mathrm{~cm}^{-1}$ (asymmetric bridge oxygen stretching), and $896 \mathrm{~cm}^{-1}$ (glycosidic bond). The results obtained were consistent with the results of previous studies [19].

\subsection{Analysis of Functional Groups in Chitosan Extracted from Black Soldier Fly}

The characteristic bands were recorded at $1650 \mathrm{~cm}^{-1}$ and $1587 \mathrm{~cm}^{-1}$ for the chitosan from BSF, and at $1649 \mathrm{~cm}^{-1}$ and $1587 \mathrm{~cm}^{-1}$ for commercial chitosan.

The characteristic peaks observed at $1650 \mathrm{~cm}^{-1}$ and $1649 \mathrm{~cm}^{-1}$ in both BSF and standard commercial chitosan were due to the presence of amide $\mathrm{I}(\mathrm{C}=\mathrm{O})$ in the acetamide group $\left(\mathrm{NHCOCH}_{3}\right)$, while the peaks observed at $1587 \mathrm{~cm}^{-1}$ in both chitosan samples were due to the amide II band $\left(\mathrm{NH}_{2}\right)$ in the $\mathrm{NHCOCH}_{3}$ group. These present findings are consistent with those reported in [19], where the author reported similar characteristic peaks using chitosan from BSF larvae and adult flies. The findings of [19] showed that the peaks at around $1650-1655 \mathrm{~cm}^{-1}$ and $1583-1590 \mathrm{~cm}^{-1}$, which correspond to $(\mathrm{C}=\mathrm{O})$ in the $\mathrm{NHCOCH}_{3}$ group (amide I band) and $\left(\mathrm{NH}_{2}\right)$ in the $\mathrm{NHCOCH}_{3}$ group (amide II band), respectively, were characteristic of chitosan.

Additional broad absorption bands observed at $3250-3750 \mathrm{~cm}^{-1}$ were attributed to symmetric stretching vibrations of the $\mathrm{O}-\mathrm{H}$ and $\mathrm{NH}_{2}$ groups caused by the strong intermolecular hydrogen bonding of chitosan polysaccharides. The peaks at approximately $2350 \mathrm{~cm}^{-1}$ were attributed to symmetric and asymmetric vibrations of $\mathrm{C}-\mathrm{H}$ groups in the chitosan samples. The absorption peaks at 1374 and $1255 \mathrm{~cm}^{-1}$ were ascribed to N-H bending vibrations of primary amides and C-O-C stretching vibrations in both chitosan samples. These findings were consistent with those obtained in [37], where the authors used chitosan derived from grasshopper species. The peaks displayed at around $1153 \mathrm{~cm}^{-1}$ and $1082 \mathrm{~cm}^{-1}$ were attributed to the $\beta(1-4)$ glycosidic bond in the polysaccharide unit and the stretching vibrations of $\mathrm{C}-\mathrm{O}-\mathrm{C}$ in the glucose ring, respectively. These findings are similar to those found in [38], where the authors used chitosan from shrimp shells.

The absorption band of amide II had a lower intensity than that of amide I, suggesting effective deacetylation. When chitin was converted to chitosan, the intensity of the amide II absorption band decreased, while the intensity of amide II increased, showing the formation of amide $\left(\mathrm{NH}_{2}\right)$ groups. The FTIR results suggest that there was a similarity between the chemical composition and the bonding types of chitosan in the pupal shells and commercial shrimp chitosan (Figure 2). These findings are similar to those reported in [39], where the authors used chitosan from nymphs and adult grasshoppers.

\subsection{Characterization of Chitin and Chitosan by Scanning Electron Microscopy (SEM)}

The surface morphology of chitin obtained from BSF pupal exuviae by B. subtilis, $P$. aeruginosa, and their co-cultivation showed a rough, tightly packed structure with repeating circular and hexagonal units in a honeycomb-like arrangement (Figure 3a-c). The biologically extracted chitin had rough surfaces, with numerous porous fibers. The pores were $50 \mu \mathrm{m}$ in diameter at X500 magnification. An increase in magnification to X1000 revealed that all of the biologically extracted chitin had fibers and pores, but low magnification gave clearer micrographs. These findings are similar to previous research on BSF pupal shell chitin reported in [19], where the surface morphology revealed a tightly packed structure with repeating circular and hexagonal units in a honeycomb-like arrangement; the author observed a rough surface with fibers and pores with a diameter of $20 \mu \mathrm{m}[19]$. 


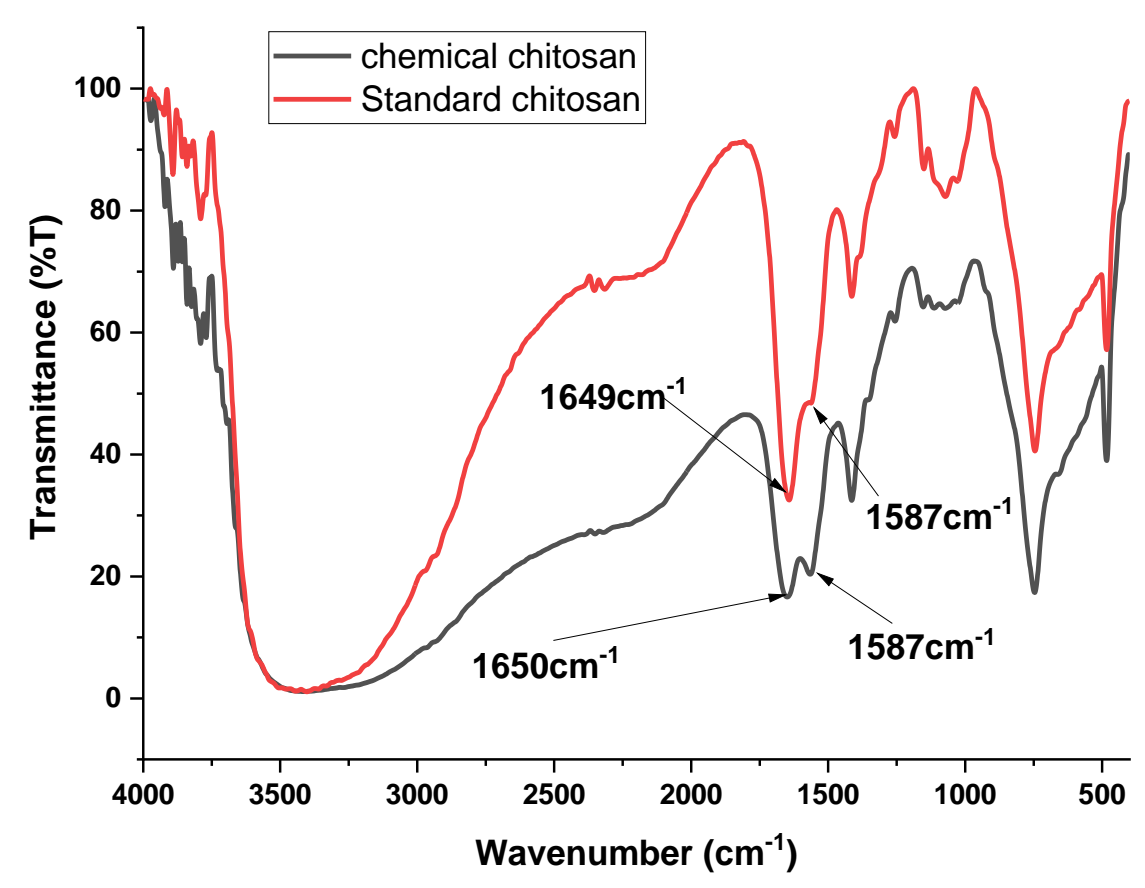

Figure 2. FTIR spectra of chemically extracted chitosan from BSF pupal exuviae, compared to the standard shrimp chitosan (Sigma-Aldrich, St. Louis, MI, USA).
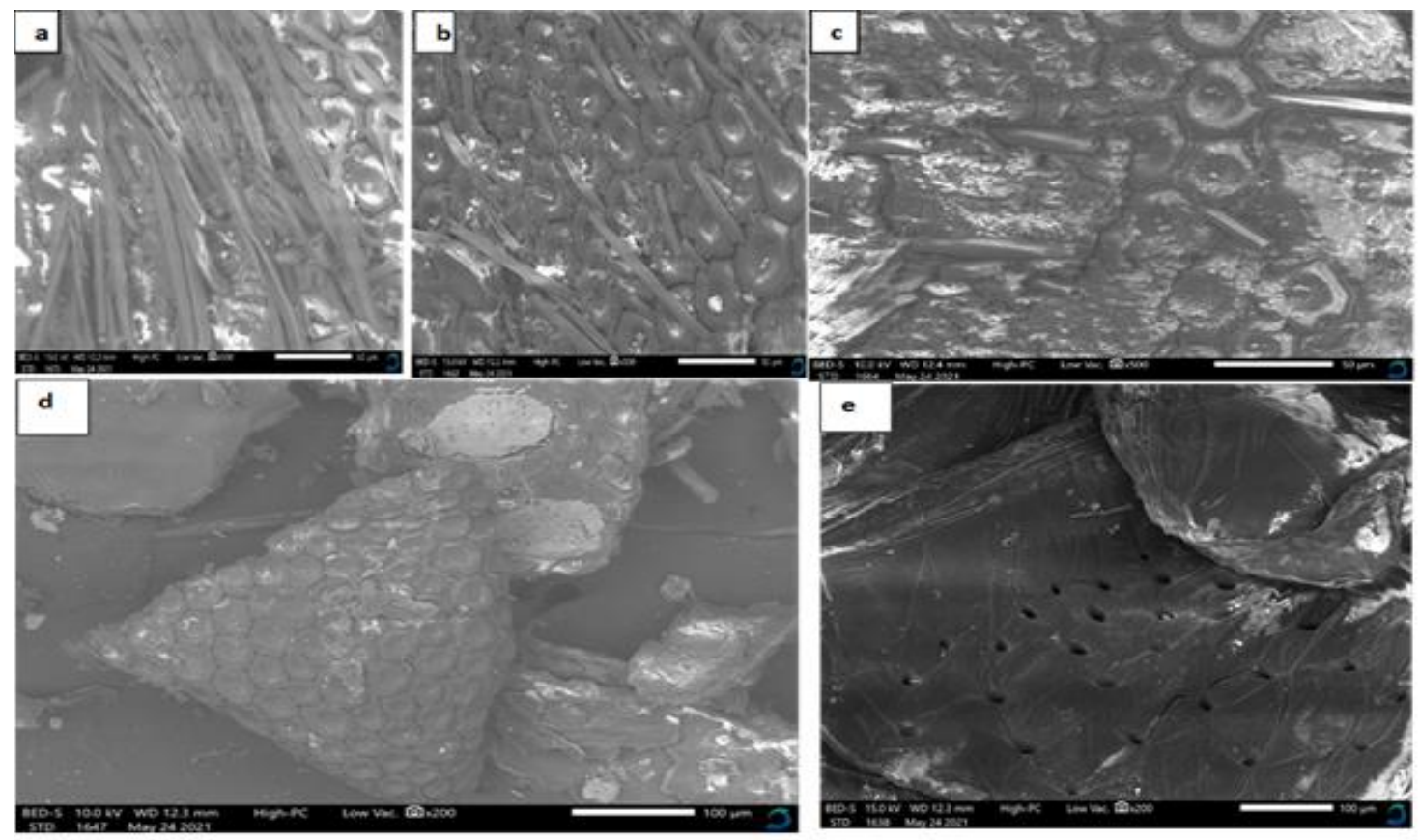

Figure 3. Scanning electron micrographs of (a) chitin from BSF pupal shells extracted by B. subtilis bacteria, (b) chitin from BSF pupal shells extracted by P. aeruginosa bacteria, (c) chitin from BSF pupal shells extracted by co-cultivation of $B$. subtilis and $P$. aeruginosa bacteria, (d) chitin from BSF pupal shells extracted via the use of chemicals, and (e) commercial shrimp chitin (Sigma-Aldrich, St. Louis, MI, USA).

On the other hand, chitin obtained via chemical means had a smooth surface with few fibers and pores, and the surface morphology revealed tightly packed structures with repeating circular and hexagonal units in a honeycomb-like arrangement (Figure 3d). These observations are similar to those of previous studies on BSF pupae chitin $[19,30]$. Commercial shrimp chitin had a rocky smooth surface, without fibers, and numerous pores 
of $100 \mu \mathrm{m}$ in diameter at X500 magnification (Figure 3e), which was similar to the findings of previous studies [19,31,40].

The BSF pupal exuviae chitosan obtained via chemical means had a rough surface, without any fibers and/or pores (Figure 4a), while commercial shrimp chitosan had a dense, smooth surface without fibers or pores (Figure $4 \mathrm{~b}$ ). The findings on the morphology of chitosan extracted from BSF pupal exuviae are consistent with previous studies done on BSF chitosan from pupal shells $[19,36]$. Commercial shrimp chitosan, on the other hand, had a dense, smooth surface without fibers and/or pores; this finding differs from the observations of previous studies conducted by several authors $[19,31,40]$.
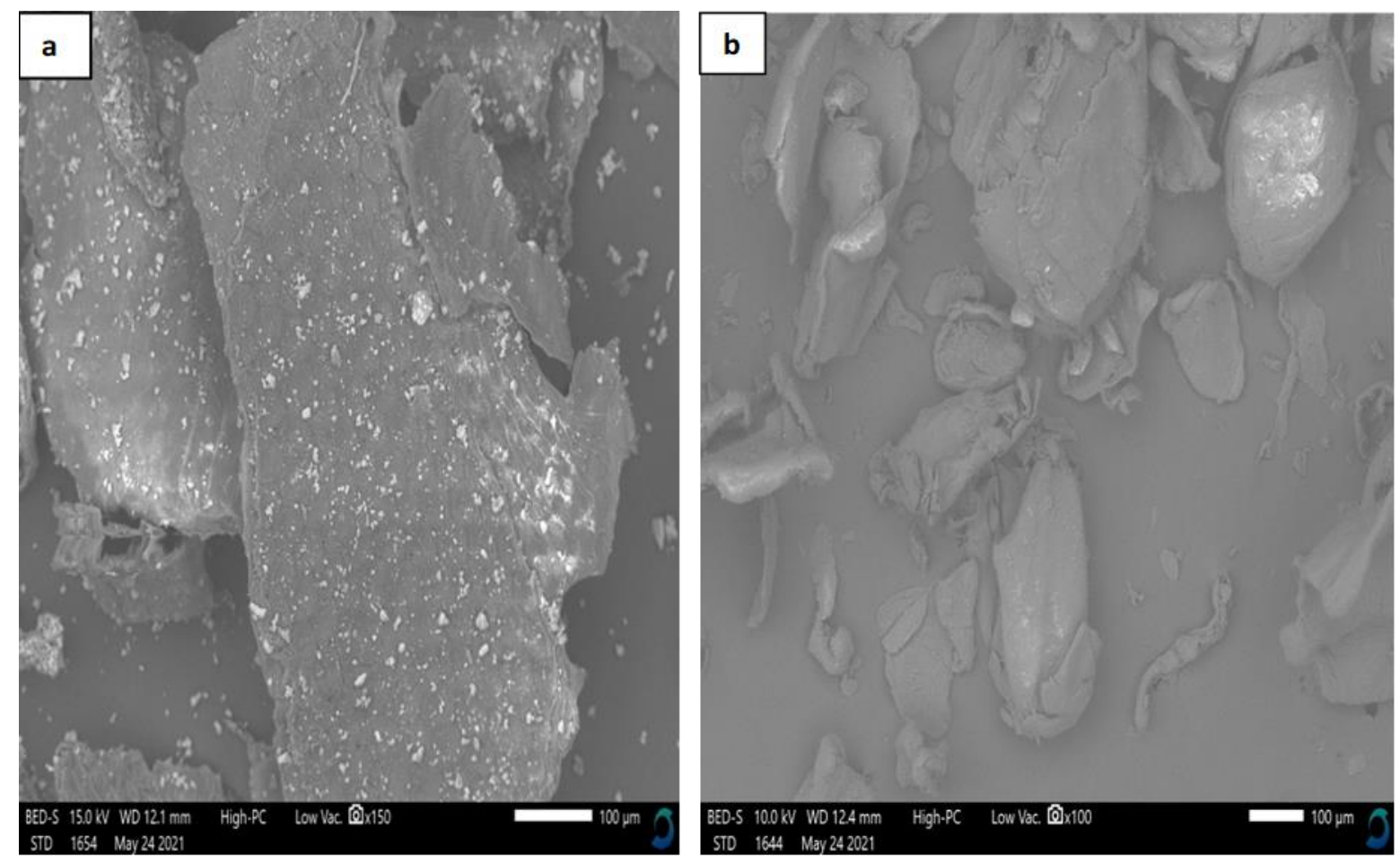

Figure 4. Scanning electron micrographs of (a) chitosan from BSF pupal shell chitin obtained via the use of chemicals, and (b) commercial shrimp chitosan (Sigma-Aldrich, St. Louis, MI, USA).

According to the literature, chitin obtained from various sources has variable morphology [41]. The surface morphology of the biologically extracted chitin from the BSF pupal exuviae in this study was similar to that of other organisms, such as crabs, grasshoppers, potato beetles, locusts, and house crickets [31,40-43].

The surface morphology of chemically extracted chitin from the BSF pupal exuviae was similar to that of other sources-for instance, fungal sources such as $L$. vellereus and P. ribis [39], and lichen species such as X. parietina [44].

Biologically and chemically extracted chitin from BSF pupal shells were similar in that chitin obtained using both techniques had rough surface morphology, the same shape, and both had pores and fibers, but biologically extracted chitin had more fibers and pores; both differed from commercial shrimp chitin in that the latter had a smooth surface, a rocky shape, and numerous pores, but no fibers. The surface morphology of chitin is critical in determining its use in different fields of application, which is consistent with the findings of many researchers $[19,41,45]$. For example, chitin with a porous structure has been employed in the absorption of toxic metal ions, used in controlled drug delivery and tissue engineering, while chitin with a fibrous structure is used in textiles [46]. 


\subsection{Antimicrobial Properties of Chitosan against Pathogenic Microbes}

The concentrations of BSF chitosan $(0.5,1,2.5$, and $5 \%)$ exhibited statistically significant differences in their activity against all of the tested organisms. Chitosan from the BSF pupal exuviae exhibited varying degrees of antibacterial activity against E. coli, S. aureus, P. aeruginosa, B. subtilis, and C. albicans. One percent (1\%) acetic acid without chitosan (positive control) demonstrated antimicrobial activity against all of the tested microbes, while the negative control (distilled water) showed no inhibitory effects (Table 2).

Table 2. The mean inhibition zones $(\mathrm{mm})$ of BSF chitosan against selected pathogenic microbes.

\begin{tabular}{|c|c|c|c|c|c|}
\hline \multicolumn{6}{|c|}{ Bacteria Species } \\
\hline Concentration $(\mathrm{g} / \mathrm{mL})$ & C. albicans & E. coli & S. aureus & B. subtilis & P. aeruginosa \\
\hline 0.5 & $14.33 \pm 3.21^{b}$ & $14.33 \pm 3.21^{b}$ & $13.33 \pm 1.53^{b}$ & $13.67 \pm 2.52^{b}$ & $14.33 \pm 0.58^{b}$ \\
\hline 1.0 & $16.67 \pm 3.21^{b}$ & $20.00 \pm 4.36^{\mathrm{c}}$ & $16.67 \pm 2.31^{\mathrm{c}}$ & $16.67 \pm 1.53^{c}$ & $16.67 \pm 1.15^{\mathrm{c}}$ \\
\hline 2.5 & $22.00 \pm 2.65^{c}$ & $25.33 \pm 2.89^{c}$ & $21.67 \pm 4.93^{\mathrm{d}}$ & $22.67 \pm 2.52^{\mathrm{d}}$ & $18.33 \pm 1.53^{\mathrm{d}}$ \\
\hline 5.0 & $26.00 \pm 3.61^{c}$ & $26.33 \pm 2.89^{c}$ & $23.33 \pm 3.79^{d}$ & $24.67 \pm 1.53^{\mathrm{d}}$ & $20.33 \pm 1.53^{d}$ \\
\hline $1 \%$ Acetic acid (+control) & $13.33 \pm 1.46^{b}$ & $11.67 \pm 1.46^{\mathrm{b}}$ & $11.67 \pm 1.46^{\mathrm{a}}$ & $10.00 \pm 1.46^{b}$ & $12.33 \pm 1.46^{b}$ \\
\hline $\begin{array}{l}\text { Sterile distilled water } \\
\text { (-control) }\end{array}$ & $0.00 \pm 1.46^{\mathrm{a}}$ & $0.00 \pm 1.46^{\mathrm{a}}$ & $0.00 \pm 1.46^{\mathrm{a}}$ & $0.00 \pm 1.46^{\mathrm{a}}$ & $0.00 \pm 1.46^{\mathrm{a}}$ \\
\hline$p$-values & 0.0081 & 0.0087 & 0.0245 & 0.0006 & 0.0023 \\
\hline
\end{tabular}

Different letters in the same column indicate significant differences $(p<0.05)$. Values are given as the mean \pm standard deviation.

The inhibitory activity against each of the tested microbes increased with the increase in the concentration of chitosan. The chitosan from BSF pupal exuviae showed the largest inhibition zone against C. albicans. These findings contrast with the findings of $[47,48]$, which reported a small inhibition zone when chitosan from grasshopper species and BSF were used, respectively. In this study, chitosan inhibited the growth of E.coli, and these findings are similar to those of previous studies that tested chitosan's activity on E. coli and found a diameter of $10 \mathrm{~mm}[49,50]$. Chitosan from H. illucens showed stronger antibacterial activity against $S$. aureus as compared to the findings of $[47,51,52]$, where the inhibition zones were 14 and 18-21 mm for $S$. aureus, respectively. On the other hand, a larger diameter of inhibition of $33 \mathrm{~mm}$ has been reported based on their findings for S. aureus [53]. The BSF chitosan demonstrated stronger activity against $P$. aeruginos $a$ and gave a diameter of inhibition of $21 \mathrm{~mm}$, which was lower compared to the findings of [53,54], with diameters of $27 \mathrm{~mm}$ and $12 \mathrm{~mm}$, respectively [53,54]. Chitosan from BSF demonstrated notable antibacterial activity against $B$. subtilis, which was consistent with previous studies [55]. The chitosan of BSF also showed stronger antifungal properties, as demonstrated by greater inhibition of $C$. albicans; this is similar to the findings of $[47,56,57]$. The activity of chitosan on C. albicans was higher than in [53]. From the results obtained, there is a possibility that chitosan derived from BSF has a higher antimicrobial quality when compared to chitosan derived from fungi or shrimp.

\subsection{Comparative Effects of the Antimicrobial Activity of Chitosan from BSF, Shrimp, and Conventional Antibiotics against Selected Pathogenic Microbes}

There were no significant differences between the activity of chitosan from BSF and that from commercial shrimp on E. coli $(p<0.05)$ (Table 3$)$. The activity of BSF and commercial chitosan on $S$. aureus, C. albicans, B. subtilis, and P. aeruginosa had a significant difference. There were no significant differences between the inhibition potential of BSF chitosan and that of the various antibiotics (nitrofurantoin, streptomycin, co-trimoxazole, and gentamycin) against $C$. albicans. No significant differences were observed in the activity of BSF chitosan and antibiotics (nalidixic acid, tetracycline, and gentamycin) against E. coli. Other test organisms (S. aureus, B. subtilis, and P. aeruginosa) were significantly inhibited by BSF chitosan and all other conventional antibiotics. However, no significant differences were observed in the activity of commercial shrimp chitosan and nitrofurantoin, 
tetracycline, streptomycin, and nalidixic acid against $S$. aureus. The activity of commercial shrimp chitosan showed no significant differences as compared to antibiotics (nitrofurantoin, tetracycline, and nalidixic acid) against B. subtilis. Amongst conventional antibiotics, gentamycin was sensitive to all of the tested microorganisms, and demonstrated the largest zones of inhibition in each of the test organisms, with B. subtilis exhibiting the highest diameter of inhibition. Ampicillin showed no inhibitory effect on any of the tested microbes. Bacillus subtilis and S. aureus were resistant to sulfathiazole, streptomycin, and co-trimoxazole. Sulfathiazole and co-trimoxazole had no inhibitory effects on P. aeruginosa. Conversely, E. coli was resistant to ampicillin only, while C. albicans was not susceptible to ampicillin or nalidixic acid. These observations are consistent with those reported by the authors of [47], who observed no inhibitory effects of ampicillin on C. albicans.

Table 3. Mean inhibition zones (mm) of BSF chitosan, shrimp chitosan, and conventional antibiotics against selected pathogenic microbes.

\begin{tabular}{|c|c|c|c|c|c|}
\hline \multicolumn{6}{|c|}{ Bacteria Species } \\
\hline Antibiotics & C. albicans & E. coli & S. aureus & B. subtilis & P. aeruginosa \\
\hline BSF chitosan & $19.75 \pm 5.48^{c}$ & $21.5 \pm 5.78^{\mathrm{d}}$ & $18.75 \pm 5.07^{b}$ & $19.42 \pm 4.96^{b}$ & $17.42 \pm 2.54^{b}$ \\
\hline Shrimp chitosan & $16.58 \pm 4.19^{\mathrm{c}}$ & $19.42 \pm 5.58^{d}$ & $15.92 \pm 5.32^{b}$ & $18.17 \pm 5.02^{b}$ & $14.83 \pm 3.16^{b}$ \\
\hline Ampicillin (25 mcg) & $0.00 \pm 1.46^{\mathrm{a}}$ & $0.00 \pm 1.46^{\mathrm{a}}$ & $0.00 \pm 1.46^{\mathrm{a}}$ & $0.00 \pm 1.46^{\mathrm{a}}$ & $0.00 \pm 1.46^{\mathrm{a}}$ \\
\hline Tetracycline (100 mcg) & $25.00 \pm 1.46^{\mathrm{c}}$ & $20.00 \pm 1.46^{\mathrm{d}}$ & $19.00 \pm 1.46^{\mathrm{b}}$ & $24.00 \pm 1.46^{\mathrm{c}}$ & $20.00 \pm 1.46^{\mathrm{c}}$ \\
\hline Nitrofurantoin $(200 \mathrm{mcg})$ & $15.00 \pm 1.46^{\mathrm{c}}$ & $15.00 \pm 1.46^{\mathrm{d}}$ & $19.00 \pm 1.46^{\mathrm{b}}$ & $18.00 \pm 1.46^{b}$ & $22.00 \pm 1.46^{\mathrm{d}}$ \\
\hline Nalidixic acid (30 mcg) & $0.00 \pm 1.46^{\mathrm{a}}$ & $27.00 \pm 1.46^{\mathrm{e}}$ & $21.00 \pm 1.46^{b}$ & $20.00 \pm 1.46^{b}$ & $20.00 \pm 1.46^{\mathrm{d}}$ \\
\hline Streptomycin (25 mcg) & $15.00 \pm 1.46^{\mathrm{c}}$ & $15.00 \pm 1.46^{\mathrm{d}}$ & $19.00 \pm 1.46^{\mathrm{b}}$ & $0.00 \pm 1.46^{\mathrm{a}}$ & $15.00 \pm 1.46^{\mathrm{b}}$ \\
\hline Sulfathiazole (200 mcg) & $10.00 \pm 1.46^{\mathrm{b}}$ & $10.00 \pm 1.46^{\mathrm{b}}$ & $0.00 \pm 1.46^{\mathrm{a}}$ & $0.00 \pm 1.46^{\mathrm{a}}$ & $0.00 \pm 1.46^{\mathrm{a}}$ \\
\hline Co-trimoxazole (25 mcg) & $17.00 \pm 1.46^{\mathrm{c}}$ & $12.00 \pm 1.46^{\mathrm{c}}$ & $0.00 \pm 1.46^{\mathrm{a}}$ & $0.00 \pm 1.46^{\mathrm{a}}$ & $0.00 \pm 1.46^{\mathrm{a}}$ \\
\hline Gentamycin (10 mcg) & $17.00 \pm 1.46^{\mathrm{c}}$ & $28.00 \pm 1.46^{\mathrm{e}}$ & $29.00 \pm 1.46^{c}$ & $31.00 \pm 1.46^{\mathrm{d}}$ & $30.00 \pm 1.46^{\mathrm{e}}$ \\
\hline$p$-Values & $<0.001$ & $<0.001$ & $<0.001$ & $<0.001$ & $<0.001$ \\
\hline
\end{tabular}

Different letters in the same column indicate significant differences $(p<0.05)$. Values are given as the mean \pm standard deviation.

BSF chitosan was found to be more effective against Gram-negative bacteria than Gram-positive bacteria in this study. These results are similar to those of many previous studies [42,58-60], which demonstrated higher activity of chitosan against Gram-negative than Gram-positive bacteria. This study, however, differs from some previous studies that demonstrated chitosan as having stronger activity against Gram-positive than Gramnegative bacteria [61-64]. The killing mechanism of chitosan has not yet been well studied, but several postulates have been proposed thus far. According to [65], the killing mechanism may be attributed to the high concentration of positive charges in the chitosan's structure, which causes strong electrostatic interactions with negatively charged residues of carbohydrates, proteins, and lipids found in microbial cells, inhibiting bacterial development [65]. It has also been suggested that chitosan alters cell permeability via deposition of chitosan on the pathogen cell surface, resulting in the formation of an impermeable polymeric layer that inhibits nutrient uptake to the cell and changes the metabolite secretions in the extracellular matrix $[60,66]$.

\section{Conclusions}

The work described in this paper demonstrates that chitin can effectively be extracted from the BSF pupal exuviae by co-cultivating P. aeruginosa and B. subtilis bacteria. Biological extraction gives high yields as compared to chemical extraction and can be used as an alternative method since it is inexpensive and eco-friendly. The FTIR results show that there was a close similarity in the chemical structure and bonding of all of the chitin samples and that they were all of the alpha form $(\alpha)$. This shows that BSF chitin can therefore be used in place of commercial shrimp chitin. Scanning electron microscopy revealed that the surface morphology of both chemical and biological chitin from BSF consisted of both fibers and pores. Chitosan from BSF exhibited activity against all of the tested 
pathogenic microbes and can therefore be used as a novel drug delivery system for a variety of therapeutic agents for combating antimicrobial-resistant strains. Further studies are needed to demonstrate the mode of action of chitosan on various microbes since the killing mechanism of chitosan remains largely unknown. Therefore, the high economic impact of chitin and chitosan extracted from BSF pupal exuviae should be further exploited for their application in the pharmaceutical, food, cosmetics, textile, wastewater treatment, and agricultural sectors.

Author Contributions: M.K.L., S.W., F.N., V.J.K., C.K. and C.M.T., conceived the experiment; M.K.L., S.W., F.N., V.J.K., C.K. and C.M.T., designed the experiment; M.K.L. and C.K., investigation; C.M.T. resources; M.K.L., writing-original draft preparation; M.K.L., S.W., F.N., V.J.K., C.K. and C.M.T. writing-review and editing; M.K.L., C.K. and C.M.T., visualization; S.W., F.N., V.J.K. and C.K., supervision; S.W., F.N., V.J.K., C.K. and C.M.T., project administration; C.M.T., funding acquisition. All authors have read and agreed to the published version of the manuscript.

Funding: Financial support for this research was provided by the Bill \& Melinda Gates Foundation (INV-032416), the Curt Bergfors Foundation Food Planet Prize Award, the Canadian International Development Research Centre (IDRC), the Australian Centre for International Agricultural Research (ACIAR) (INSFEED—Phase 2: Cultivate Grant No: 108866-001), the Norwegian Agency for Development Cooperation, the Section for Research, Innovation, and Higher Education grant number RAF-3058 KEN-18/0005 (CAP-Africa), the Netherlands Organization for Scientific Research, WOTRO Science for Global Development (NWO-WOTRO) (ILIPA-W 08.250.202), and the Rockefeller Foundation (SiPFeed-Grant No: 2018 FOD 009). We also gratefully acknowledge the support of the International Centre of Insect Physiology and Ecology (icipe)'s core funding provided by the United Kingdom's Foreign, Commonwealth, and Development Office (FCDO); the Swedish International Development Cooperation Agency (Sida); the Swiss Agency for Development and Cooperation (SDC); the Federal Democratic Republic of Ethiopia; and the Government of the Republic of Kenya. The funders had no role in the study design, the data collection, and analysis, the decision to publish, or the preparation of the manuscript; therefore, the views expressed herein do not necessarily reflect the official opinion of the donors.

Institutional Review Board Statement: Ethical approval for the study was provided by the Institutional Animal Care and Use Committee (IACUC) of Kenya Agricultural and Livestock Research Organization (KALRO)-Veterinary Science Research Institute (VSRI); approval Code No.: KALROVSRI/IACUC019/30082019.

Informed Consent Statement: Not applicable.

Data Availability Statement: All datasets presented in this study are included in the article and can be availed by the authors upon reasonable request.

Acknowledgments: The authors would like to acknowledge the support of Jomo Kenyatta University's lab technicians.

Conflicts of Interest: The authors declare that there is no conflict of interest regarding this work.

\section{References}

1. Kumar, M.; Rajput, M.; Soni, T.; Vivekanand, V.; Pareek, N. Chemoenzymatic production and engineering of chitooligosaccharides and $\mathrm{N}$-acetyl glucosamine for refining biological activities. Front. Chem. 2020, 8, 469. [CrossRef]

2. Joseph, S.M.; Krishnamoorthy, S.; Paranthaman, R.; Moses, J.; Anandharamakrishnan, C. A review on source-specific chemistry, functionality, and applications of chitin and chitosan. Carbohydr. Polym. Technol. Appl. 2021, 2, 100036. [CrossRef]

3. Nechita, P. Applications of chitosan in wastewater treatment. Biol. Act. Appl. Mar. Polysacch. 2017, 1, 209-228. [CrossRef]

4. Moreno-Sader, K.; Meramo-Hurtado, S.; González-Delgado, A. Environmental sustainability analysis of chitosan microbeads production for pharmaceutical applications via computer-aided simulation, WAR and TRACI assessments. Sustain. Chem. Pharm. 2020, 15, 100212. [CrossRef]

5. Yang, H.; Zhang, Y.; Zhou, F.; Guo, J.; Tang, J.; Han, Y.; Li, Z.; Fu, C. Preparation, bioactivities and applications in food industry of chitosan-based maillard products: A review. Molecules 2020, 26, 166. [CrossRef]

6. Shahrajabian, M.; Chaski, C.; Polyzos, N.; Tzortzakis, N.; Petropoulos, S. Sustainable agriculture systems in vegetable production using chitin and chitosan as plant biostimulants. Biomolecules 2021, 11, 819. [CrossRef] [PubMed]

7. El Knidri, H.; Belaabed, R.; Addaou, A.; Laajeb, A.; Lahsini, A. Extraction, chemical modification and characterization of chitin and chitosan. Int. J. Biol. Macromol. 2018, 120, 1181-1189. [CrossRef] [PubMed] 
8. Pachapur, V.L.; Guemiza, K.; Rouissi, T.; Sarma, S.J.; Brar, S.K. Novel biological and chemical methods of chitin extraction from crustacean waste using saline water. J. Chem. Technol. Biotechnol. 2016, 91, 2331-2339. [CrossRef]

9. Zainol Abidin, N.A.; Kormin, F.; Zainol Abidin, N.A.; Mohamed Anuar, N.A.F.; Abu Bakar, M.F. The potential of insects as alternative sources of chitin: An overview on the chemical method of extraction from various sources. Int. J. Mol. Sci. 2020, 21, 4978. [CrossRef] [PubMed]

10. Tan, Y.N.; Lee, P.P.; Chen, W.N. Microbial extraction of chitin from seafood waste using sugars derived from fruit waste-stream. AMB Express 2020, 10, 1-11. [CrossRef] [PubMed]

11. Chai, J.; Hang, J.; Zhang, C.; Yang, J.; Wang, S.; Liu, S.; Fang, Y. Purification and characterization of chitin deacetylase active on insoluble chitin from Nitratireductor aquimarinus MCDA3-3. Int. J. Biol. Macromol. 2020, 152, 922-929. [CrossRef]

12. Achur, R.N. Isolation and characterization of chitin from Millipede (Spirobolida). J. Basic Appl. Zool. 2018, 79, 30. [CrossRef]

13. Marmier, T.; Szczepanski, C.R.; Candet, C.; Zenerino, A.; Godeau, R.-P.; Godeau, G. Investigation on Mecynorhina torquata Drury, 1782 (Coleoptera, Cetoniidae, Goliathini) cuticle: Surface properties, chitin and chitosan extraction. Int. J. Biol. Macromol. 2020, 164, 1164-1173. [CrossRef]

14. Mohan, K.; Ganesan, A.R.; Muralisankar, T.; Jayakumar, R.; Sathishkumar, P.; Uthayakumar, V.; Chandirasekar, R.; Revathi, N. Recent insights into the extraction, characterization, and bioactivities of chitin and chitosan from insects. Trends Food Sci. Technol. 2020, 105, 17-42. [CrossRef] [PubMed]

15. Vetter, J. Chitin content of cultivated mushrooms Agaricus bisporus, Pleurotus ostreatus and Lentinula edodes. Food Chem. 2007, 102, 6-9. [CrossRef]

16. Ospina Álvarez, S.P.; Ramírez Cadavid, D.A.; Escobar Sierra, D.M.; Ossa Orozco, C.P.; Rojas Vahos, D.F.; Zapata Ocampo, P.; Atehortúa, L. Comparison of extraction methods of chitin from Ganoderma lucidum mushroom obtained in submerged culture. BioMed Res. Int. 2014, 169071. [CrossRef]

17. Hassainia, A.; Satha, H.; Boufi, S. Chitin from Agaricus bisporus: Extraction and characterization. Int. J. Biol. Macromol. 2018, 117, 1334-1342. [CrossRef] [PubMed]

18. Shumo, M.; Osuga, I.M.; Khamis, F.M.; Tanga, C.M.; Fiaboe, K.K.M.; Subramanian, S.; Ekesi, S.; Van Huis, A.; Borgemeister, C. The nutritive value of black soldier fly larvae reared on common organic waste streams in Kenya. Sci. Rep. 2019, 9, 1-13. [CrossRef]

19. Zimri, M.N. Preparation and Electrospinning of Chitosan from Waste Black Soldier Fly Biomass; University of the Western Cape: Cape Town, South Africa, 2018.

20. Aytekin, O.; Elibol, M. Cocultivation of Lactococcus lactis and Teredinobacter turnirae for biological chitin extraction from prawn waste. Bioprocess. Biosyst. Eng. 2009, 33, 393-399. [CrossRef]

21. Kaur, S.; Dhillon, G.S. Recent trends in biological extraction of chitin from marine shell wastes: A review. Crit. Rev. Biotechnol. 2015, 35, 44-61. [CrossRef]

22. Akram, K.; Ahn, J.-J.; Kwon, J.-H. Identification and characterization of gamma-irradiated dried Lentinus edodes using ESR, SEM, and FTIR analyses. J. Food Sci. 2012, 77, C690-C696. [CrossRef] [PubMed]

23. Kourmouli, A.; Valenti, M.; Van Rijn, E.; Beaumont, H.J.E.; Kalantzi, O.-I.; Schmidt-Ott, A.; Biskos, G. Can disc diffusion susceptibility tests assess the antimicrobial activity of engineered nanoparticles? J. Nano. Res. 2018, 20, 1-6. [CrossRef] [PubMed]

24. Spranghers, T.; Ottoboni, M.; Klootwijk, C.; Ovyn, A.; Deboosere, S.; De Meulenaer, B.; Michiels, J.; Eeckhout, M.; De Clercq, P.; De Smet, S. Nutritional composition of black soldier fly (Hermetia illucens) prepupae reared on different organic waste substrates. J. Sci. Food Agric. 2017, 97, 2594-2600. [CrossRef] [PubMed]

25. Caligiani, A.; Marseglia, A.; Leni, G.; Baldassarre, S.; Maistrello, L.; Dossena, A.; Sforza, S. Composition of black soldier fly prepupae and systematic approaches for extraction and fractionation of proteins, lipids and chitin. Food Res. Int. 2018, 105, 812-820. [CrossRef]

26. Wong, C.-Y.; Rosli, S.S.; Uemura, Y.; Ho, Y.C.; Leejeerajumnean, A.; Kiatkittipong, W.; Cheng, C.-K.; Lam, M.-K.; Lim, J.-W. Potential protein and biodiesel sources from black soldier fly larvae: Insights of larval harvesting instar and fermented feeding medium. Energies 2019, 12, 1570. [CrossRef]

27. Złotko, K.; Waśko, A.; Kamiński, D.; Budziak-Wieczorek, I.; Bulak, P.; Bieganowski, A. Isolation of chitin from black soldier fly (Hermetia illucens) and its usage to metal sorption. Polymers 2021, 13, 818. [CrossRef]

28. Hajji, S.; Younes, I.; Ghorbel-Bellaaj, O.; Hajji, R.; Rinaudo, M.; Nasri, M.; Jellouli, K. Structural differences between chitin and chitosan extracted from three different marine sources. Int. J. Biol. Macromol. 2014, 65, 298-306. [CrossRef]

29. Hahn, T.; Tafi, E.; Paul, A.; Salvia, R.; Falabella, P.; Zibek, S. Current state of chitin purification and chitosan production from insects. J. Chem. Technol. Biotechnol. 2020, 95, 2775-2795. [CrossRef]

30. Erdogan, S.; Kaya, M. High similarity in physicochemical properties of chitin and chitosan from nymphs and adults of a grasshopper. Int. J. Biol. Macromol. 2016, 89, 118-126. [CrossRef]

31. Marei, N.H.; El-Samie, E.A.; Salah, T.; Saad, G.R.; Elwahy, A.H. Isolation and characterization of chitosan from different local insects in Egypt. Int. J. Biol. Macromol. 2016, 82, 871-877. [CrossRef]

32. Sargin, I.; Arslan, G.; Kaya, M. Production of magnetic chitinous microcages from ephippia of zooplankton Daphnia longispina and heavy metal removal studies. Carbohydr. Polym. 2019, 207, 200-210. [CrossRef]

33. Hossain, M.; Iqbal, A. Production and characterization of chitosan from shrimp waste. J. Bangladesh Agric. Univ. 2014, 12, 153-160. [CrossRef] 
34. Kim, M.-W.; Han, Y.S.; Jo, Y.H.; Choi, M.H.; Kang, S.H.; Kim, S.-A.; Jung, W.-J. Extraction of chitin and chitosan from housefly, Musca domestica, pupa shells. Entomol. Res. 2016, 46, 324-328. [CrossRef]

35. Yuan, Y.; Chen, L.; Shi, W.; Wang, Z.; Zhang, H. Insight into physicochemical, rheological, and antibacterial properties of chitosan extracted from Antarctic krill: A comparative study. Molecules 2020, 25, 4074. [CrossRef] [PubMed]

36. Kaya, M.; Sofi, K.; Sargin, I.; Mujtaba, M. Changes in physicochemical properties of chitin at developmental stages (larvae, pupa and adult) of Vespa crabro (wasp). Carbohydr. Polym. 2016, 145, 64-70. [CrossRef]

37. Tsurkan, M.V.; Voronkina, A.; Khrunyk, Y.; Wysokowski, M.; Petrenko, I.; Ehrlich, H. Progress in chitin analytics. Carbohydr. Polym. 2021, 252, 117204. [CrossRef]

38. Eddya, M.; Tbib, B.; El-Hami, K. A comparison of chitosan properties after extraction from shrimp shells by diluted and concentrated acids. Heliyon 2020, 6, e03486. [CrossRef] [PubMed]

39. Erdogan, S.; Kaya, M.; Akata, I. Chitin Extraction and Chitosan Production from Cell Wall of Two Mushroom Species (Lactarius vellereus and Phyllophora ribis); AIP Publishing LLC: Melville, NY, USA, 2017; Volume 1809, p. 020012.

40. Ibitoye, B.E.; Lokman, I.H.; Hezmee, M.N.M.; Goh, Y.-M.; Zuki, A.B.Z.; Jimoh, A.A. Extraction and physicochemical characterization of chitin and chitosan isolated from house cricket. Biomed. Mater. 2017, 13, 025009. [CrossRef]

41. Al Sagheer, F.; Al-Sughayer, M.; Muslim, S.; Elsabee, M. Extraction and characterization of chitin and chitosan from marine sources in Arabian Gulf. Carbohydr. Polym. 2009, 77, 410-419. [CrossRef]

42. Kaya, M.; Baran, T.; Erdoğan, S.; Menteş, A.; Özüsağlam, M.A.; Çakmak, Y.S. Physicochemical comparison of chitin and chitosan obtained from larvae and adult Colorado potato beetle (Leptinotarsa decemlineata). Mater. Sci. Eng. C 2014, 45, 72-81. [CrossRef] [PubMed]

43. Kaya, M.; Erdogan, S.; Mol, A.; Baran, T. Comparison of chitin structures isolated from seven Orthoptera species. Int. J. Biol. Macromol. 2015, 72, 797-805. [CrossRef]

44. Kaya, M.; Halıc1, M.G.; Duman, F.; Erdoğan, S.; Baran, T. Characterisation of $\alpha$-chitin extracted from a lichenised fungus species Xanthoria parietina. Nat. Prod. Res. 2015, 29, 1280-1284. [CrossRef] [PubMed]

45. Younes, I.; Rinaudo, M. Chitin and chitosan preparation from marine sources. Structure, properties and applications. Mar. Drugs 2015, 13, 1133-1174. [CrossRef] [PubMed]

46. Wang, H.; Rehman, K.U.; Feng, W.; Yang, D.; Rehman, R.U.; Cai, M.; Zhang, J.; Yu, Z.; Zheng, L. Physicochemical structure of chitin in the developing stages of black soldier fly. Int. J. Biol. Macromol. 2020, 149, 901-907. [CrossRef]

47. Kaya, M.; Baran, T.; Asan-Ozusaglam, M.; Cakmak, Y.S.; Tozak, K.O.; Mol, A.; Menteş, A.; Sezen, G. Extraction and characterization of chitin and chitosan with antimicrobial and antioxidant activities from cosmopolitan Orthoptera species (Insecta). Biotechnol. Bioprocess. Eng. 2015, 20, 168-179. [CrossRef]

48. Leke-Aladekoba, A.A. Comparison of Extraction Methods and Characterisation of Chitin and Chitosan with Antimicrobial and Antioxidant Properties from Black Soldier Fly (Hermetia illucens) Meal. Master's Thesis, Dalhousie University, Nova Scotia, Canada, 2018.

49. Al-Nabulsi, A.; Osaili, T.; Sawalha, A.; Olaimat, A.N.; Albiss, B.A.; Mehyar, G.; Ayyash, M.; Holley, R. Antimicrobial activity of chitosan coating containing $\mathrm{ZnO}$ nanoparticles against E. coli O157:H7 on the surface of white brined cheese. Int. J. Food Microbiol. 2020, 334, 108838. [CrossRef]

50. Alfaifi, M.Y.; Alkabli, J.; Elshaarawy, R.F. Suppressing of milk-borne pathogenic using new water-soluble chitosan-azidopropanoic acid conjugate: Targeting milk-preservation quality improvement. Int. J. Biol. Macromol. 2020, 164, 1519-1526. [CrossRef]

51. Divya, K.; Vijayan, S.; George, T.K.; Jisha, M.S. Antimicrobial properties of chitosan nanoparticles: Mode of action and factors affecting activity. Fibers Polym. 2017, 18, 221-230. [CrossRef]

52. Elshaarawy, R.F.; Ismail, L.A.; Alfaifi, M.Y.; Rizk, M.A.; Eltamany, E.; Janiak, C. Inhibitory activity of biofunctionalized silvercapped N-methylated water-soluble chitosan thiomer for microbial and biofilm infections. Int. J. Biol. Macromol. 2020, 152, 709-717. [CrossRef]

53. Khalil, A.M.; Abdel-Monem, R.A.; Darwesh, O.M.; Hashim, A.I.; Nada, A.A.; Rabie, S.T. Synthesis, characterization, and evaluation of antimicrobial activities of chitosan and carboxymethyl chitosan schiff-base/silver nanoparticles. J. Chem. 2017, 2017, 1434320. [CrossRef]

54. Umoren, S.A.; Solomon, M.M.; Nzila, A.; Obot, I.B. Preparation of silver/chitosan nanofluids using selected plant extracts: Characterization and antimicrobial studies against gram-positive and gram-negative bacteria. Materials 2020, 13, 1629. [CrossRef]

55. Dash, S.; Kumar, M.; Pareek, N. Enhanced antibacterial potential of berberine via synergism with chitosan nanoparticles. Mater. Today Proc. 2020, 31, 640-645. [CrossRef]

56. Namangkalakul, W.; Benjavongkulchai, S.; Pochana, T.; Promchai, A.; Satitviboon, W.; Howattanapanich, S.; Phuprasong, R.; Ungvijanpunya, N.; Supakanjanakanti, D.; Chaitrakoonthong, T.; et al. Activity of chitosan antifungal denture adhesive against common Candida species and Candida albicans adherence on denture base acrylic resin. J. Prosthet. Dent. 2020, 123, 181.e1-181.e7. [CrossRef] [PubMed]

57. Khan, S.H.; Younus, H.; Allemailem, K.S.; Almatroudi, A.; Alrumaihi, F.; Alruwetei, A.M.; Alsahli, M.A.; Khan, A.; Alam Khan, M. Potential of methylglyoxal-conjugated chitosan nanoparticles in treatment of fluconazole-resistant Candida albicans infection in a murine model. Int. J. Nanomed. 2020, 15, 3681-3693. [CrossRef]

58. Choi, W.H.; Yun, J.H.; Chu, J.P.; Chu, K.B. Antibacterial effect of extracts of Hermetia illucens (Diptera Stratiomyidae) larvae against G ram-negative bacteria. Entomol. Res. 2012, 42, 219-226. [CrossRef] 
59. Hipalaswins, W.M.; Balakumaran, M.; Jagadeeswari, S. Synthesis, characterization and antibacterial activity of chitosan nanoparticles and its impact on seed germination. J. Acad. Ind. Res. 2016, 5, 65.

60. Chandrasekaran, M.; Kim, K.D.; Chun, S.C. Antibacterial activity of chitosan nanoparticles: A review. Processes 2020, 8, 1173. [CrossRef]

61. Silva, C.; Matamá, T.; Kim, S.; Padrão, J.; Prasetyo, E.N.; Kudanga, T.; Nyanhongo, G.S.; Guebitz, G.M.; Casal, M.; Cavaco-Paulo, A. Antimicrobial and antioxidant linen via laccase-assisted grafting. React. Funct. Polym. 2011, 71, 713-720. [CrossRef]

62. Abdallah, O.M.; El-Baghdady, K.Z.; Khalil, M.; El Borhamy, M.I.; Meligi, G.A. Antibacterial, antibiofilm and cytotoxic activities of biogenic polyvinyl alcohol-silver and chitosan-silver nanocomposites. J. Polym. Res. 2020, 27, 1-9. [CrossRef]

63. Kipkoech, C.; Kinyuru, J.N.; Imathiu, S.; Meyer-Rochow, V.B.; Roos, N. In vitro study of cricket chitosan's potential as a prebiotic and a promoter of probiotic microorganisms to control pathogenic bacteria in the human gut. Foods 2021, 10, 2310. [CrossRef]

64. Shapi'I, R.A.; Othman, S.H.; Nordin, N.; Basha, R.K.; Naim, M.N. Antimicrobial properties of starch films incorporated with chitosan nanoparticles: In vitro and in vivo evaluation. Carbohydr. Polym. 2020, 230, 115602. [CrossRef] [PubMed]

65. Homaeigohar, S.; Boccaccini, A.R. Antibacterial biohybrid nanofibers for wound dressings. Acta Biomater. 2020, 107, 25-49. [CrossRef] [PubMed]

66. Youssef, K.; Hashim, A.F. Inhibitory effect of clay/chitosan nanocomposite against Penicillium digitatum on citrus and its possible mode of action. Jordan J. Biol. Sci. 2020, 13, 349-355. 